\title{
Effects of Tectonic Stresses and Structural Planes on Slope Deformation and Stability at the Buzhaoba Open Pit Mine, China
}

(Kesan Tekanan Tektonik dan Satah Struktur pada Canggaan Cerun dan Kestabilan di Lombong Terbuka, Buzhaoba, China)

\author{
ShuZhao Chen, Goh Thian LaI*, LiU Han \& Gerson. S.V. Tovele
}

\begin{abstract}
Tectonic stresses and structural planes are key factors that affect slope stability. The studies of the effect mechanism of the two factors on the slope deformation and instability have an important value for realizing an accurate evaluation of slope stability. The deformation and landslide problems of the west slope at the Buzhaoba open pit mine were analyzed. Tectonic stresses and structural planes were confirmed as the main factors of long-term deformation of the slope. According to an analysis of the regional structure, the principal stress direction of the Buzhaoba mine was $123^{\circ}$ and the slope sliding mode and discriminant conditions were determined under the influence of tectonic stress. The principal stress direction was verified by comparison with the results of displacement monitoring and stability analysis of the slope. The factor of safety of the slope is 1.29 when considering tectonic stress and reduces by $7.19 \%$ when tectonic stress is not considered.
\end{abstract}

Keywords: Fault; open pit mine; slope stability; structural plane; tectonic stresses

ABSTRAK

Tegasan tektonik dan satah struktur adalah faktor utama yang mempengaruhi kestabilan cerun. Kajian mekanisme kesan dua faktor pada kecerunan dan ketidakstabilan cerun mempunyai nilai penting dalam mewujudkan penilaian kestabilan cerun yang tepat. Masalah kecanggaan dan tanah runtuh di cerun barat di lombong terbuka Buzhaoba telah dikaji. Tegasan tektonik dan satah struktur telah disahkan sebagai faktor utama dalam perubahan kecanggaan jangka panjang cerun. Mengikut analisis struktur serantau, arahan tegasan utama lombong Buzhaoba adalah $123^{\circ}$ dan mod gelongsor cerun dan syarat diskriminasi ditentukan di bawah pengaruh tegasan tektonik. Arah tegasan utama disahkan berdasarkan perbandingan dengan hasil pemantauan anjakan dan analisis kestabilan cerun. Faktor keselamatan cerun adalah 1.29 apabila mengambil kira tegasan tektonik dan menurun sebanyak 7.19\% apabila tegasan tektonik tidak diambil kira.

Kata kunci: Kestabilan cerun; lombong pit terbuka; satah struktur; sesar; tegasan tektonik

\section{INTRODUCTION}

Mineral resources useful to human beings all occur in the crust, and open pit mining to retrieve these resources results in high and steep slopes (Yang et al. 2012). Open pit mining forms slopes with large geometric size (Chen et al. 2017). The stability of the slope is influenced by many factors including the slope structure (Zhou et al. 2016), stress state (Zhao et al. 2011), rock mass strength (Cai et al. 2007), shock load (Hack et al. 2007; Han et al. 2015) and hydraulic condition (Shu et al. 2012). The main origin of slope deformation and instability varies with the details of the specific engineering geological conditions. Typically, different experts and scholars have different opinions regarding similar engineering problems. Therefore, to accurately evaluate the key factors of slope deformation and instability is of great significance for slope stability evaluation and management.

The open pit mine slope is affected by complex interaction structures and the tectonic stresses in the crust (Wang et al. 2016). As the stress equilibrium state is disrupted in the mining process, the unbalanced stress inside the slope unloads frequently, which brings a series of safety problems to the slope. The rock mass structural plane and tectonic stress can both cause slope deformation and instability. Many scholars have studied these problems and found a variety of useful results (Nian et al. 2012; Yoon et al. 2002).

Landslide disasters can occur in many parts of the world and their consequences are generally determined by human activities and natural phenomena (Han et al. 2014). Multiple major factors can cause landslides, such as rain (Chen et al. 2012), earthquakes (Chang et al. 2011), groundwater pressure (Rohmer 2014), and the slope angle (Pradhan 2013). The relationships between tectonic stress and slope stability have been previously characterized (Mohamad et al. 2010; Tan et al. 2014) and researchers in this area have obtained important achievements (Can et al. 2013; Shen et al. 2014; Taha et al. 2012).

Tectonic stress is an important external load that affects the stability of a slope. The tectonic stress will 
increase the sliding force of sliding body towards the free surface and affects the slope stability. Zuza et al. (2017) studied the spacing effects on the strength of active continental strike-slip faults and discovered that the mean friction coefficient of the faults in the San Andreas Fault system is substantially greater than that of the strikeslip faults in the India-Asia collisional orogeny. Martel (2016) researched the actions of regular small-amplitude topography on complex ground stress as a result of gravity and tectonics, and the findings indicated that both regional compression and gravity generated compression parallel to the ridge crest line. Xia et al. (2016), who focused on the mining-induced rock movement in the region that was affected by tectonic stress, divided the region into three different zones: A stability zone, a toppling zone and a landslide zone.

The most important problems in the stability of weak rock slopes in open pit mining are the presence of discontinuities and associated problems (Wang \& Huang 2009). Geological structures within open pit mine slopes are very important when evaluating a slope as a potential developmental site or for construction. Through longterm studies, it has been shown that bedding planes, faults, cleavage and joints are the major geological structures affecting the slope stability in open pit mines (Fell et al. 2005; Wyllie et al. 2004). Problems with faults in weak rock slopes have led to several detrimental slope failures over the years and have grown to be of considerable concern to mining and geotechnical engineers. Generally, the strata plane and strength are disturbed severely by the fault as it supplies a lateral or bottom discharge plane. However, the slope stability always depends on the shear strength available along such surfaces.

The structural plane and tectonic stress inside of the slope have an important effect on the slope stability. Complex geological structures and large tectonic stresses in Western China, particularly in Yunnan, Guizhou, Sichuan Province and other regions. These factors play important roles in slope stability control in these areas to accurately find the main factors causing the instability of the slope.

\section{INFLUENCES OF THE STRUCTURAL PLANE AND TECTONIC STRESS ON THE SLOPE STABILITY INFLUENCE OF THE STRUCTURAL PLANE}

The structural plane of rock mass refers to some discontinuity planes, which have certain scales, occurrences, forms and features in terms of geological characteristics and are generally formed by tectonic movements and diagenesis in the crust. Because the structural plane is discontinuous, this plane divides the complete rock into several structures with different sizes and shapes, and the strength of the secondary structure is greatly reduced relative to that of intact rock. In general, the distribution laws of the discontinuous structural planes within rock strata and the structure in slopes have significant effects on the stability of rock stratum engineering.
The rock mass structural plane mainly includes microcracks, soft interlayers, joints, schistosities, lamellations, beddings, and faults and fractured zones. The strength of the structural plane is weaker than that of rock mass, therefore, this plane is easily broken and is significantly affected by factors such as groundwater and weathering. Under the long-term influence of the natural environment, the gaps within the structural plane tend to be easily filled by secondary minerals, which lowers the shear strength of the rock mass structural plane significantly and damages the integrity of the rock mass. This mechanism may explain why landslides occur easily along structural planes.

\section{INFLUENCE OF TECTONIC STRESSES}

Tectonic stress is caused by crustal movements and can be divided into two classes: Activities and residual stress. The activity of tectonic stress currently accumulates in the crust and can lead to rock deformation and fracture. This stress has a close relationship with the stability of the slope.

Excavation changes the stress of the rock stratum border, and predicting the degree of stress concentration has a complex effect on slope stability. As a high steep slope in an open pit mine lacks effective support at the free surface, under the long-term effects of stress, the rock mass exhibits deformation and instability along the direction of principal stress. Long-standing tectonic stress is the main reason for the continuous deformation of slopes at open pit mines in some areas of China. Therefore, in the process of large-scale geotechnical engineering construction, efforts to ensure that the free surface of the slope avoids the principal stress direction have a beneficial effect on slope stability.

\section{MATERIALS AND METHODS}

\section{GEOLOGY OF THE BUZHAOBA OPEN PIT MINE}

The research zone extends approximately $21.0 \mathrm{~km}^{2}$ and the latitudes and longitudes of the geographical center are $103^{\circ} 11^{\prime} 52^{\prime \prime} \mathrm{E}$ and $23^{\circ} 48^{\prime} 45^{\prime \prime} \mathrm{N}$, respectively, which is located within Kaiyuan City, China (Figure 1). The influence of tectonic movement has resulted in a substantial altitude difference in the research zone of $1600 \mathrm{~m}$ (from 900 to $2500 \mathrm{~m}$ ). In this area, the average annual rainfall is $700 \mathrm{~mm}$ and mainly occurs from May to October. The minimum and maximum temperature occurs in February and August, respectively, the temperature ranges from $10.9^{\circ} \mathrm{C}$ to $20.4^{\circ} \mathrm{C}$ and the average annual temperature in this area is $19.8^{\circ} \mathrm{C}$

Tectonic movement has caused the Buzhaoba mine to form a tectonic basin. After decades of mining engineering, the slope of the mine is very large, with a length of $1.8 \mathrm{~km}$ and a width of $1.45 \mathrm{~km}$. The length direction is from east to west, and the width direction is from south to north. The height of the western slope is $180 \mathrm{~m}$ and the overall slope angle ranges from $15^{\circ}$ to $25^{\circ}$. 


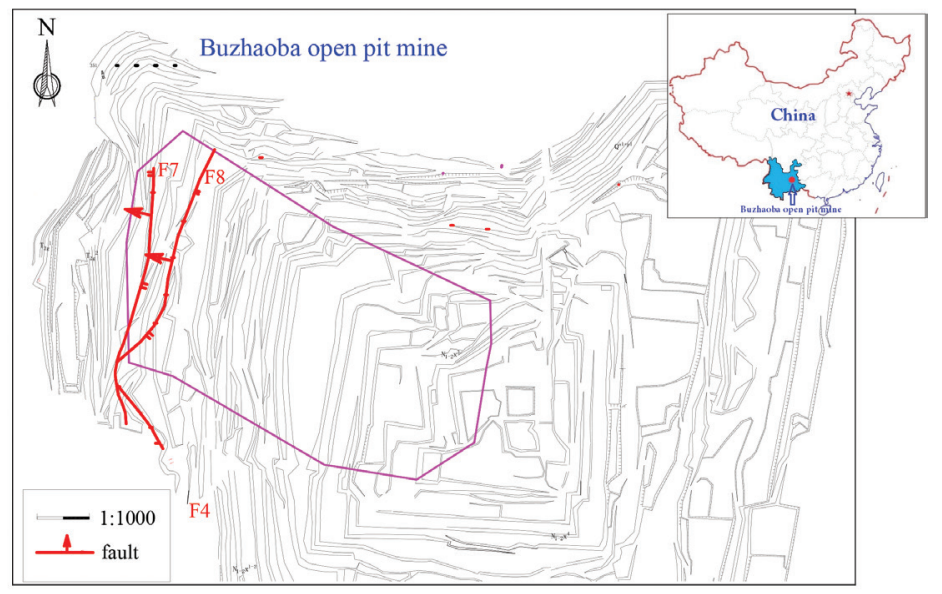

FIGURE 1. Location of the Buzhaoba open pit mine and the deformation of the west slope

There are three strata in the west slope; from the top to bottom, they are the quaternary strata, the new tertiary and the middle Triassic Gejiu group. The quaternary strata mainly include the quaternary artificial earth fill, eluvial layer and flood alluvial layer. The density of the quaternary strata is loose; as influenced by the structure plane, the thickness of rock mass ranges from $3 \mathrm{~m}$ to $15.5 \mathrm{~m}$. The new tertiary includes marl $\left(\mathrm{N}_{1-2} \mathrm{x}^{4}\right)$, the main coal seam $\left(\mathrm{N}_{1-2} \mathrm{x}^{3}\right)$, a thin coal seam $\left(\mathrm{N}_{1-2} \mathrm{x}^{2}\right)$ and the Dongshengqiao clay rock section $\left(\mathrm{N}_{1-2} \mathrm{x}^{1}\right)$. The middle Triassic Gejiu group contains dolomite-marl $\left(\mathrm{T}_{2} \mathrm{~g}^{3}\right)$, black limestone $\left(\mathrm{T}_{2} \mathrm{~g}^{2}\right)$ and mudstone-argillaceous limestone $\left(\mathrm{T}_{2} \mathrm{~g}^{1}\right)$. The west slope of the mine has a weak clay rock foundation.

In 1992, a crack appeared on the top of the west slope and the length of the crack has since developed year by year. In July 2009, the average displacement of monitoring points on the west slope was $430 \mathrm{~mm}$, the strain rate was more than $14 \mathrm{~mm} / \mathrm{d}$ and the maximum monthly displacement was as high as $1400 \mathrm{~mm}$ and presented an accelerated deformation trend. In 2010, deformation of the west slope caused the road to fracture, forcing the road to be demolished. A field investigation found that the crack on the top of west slope extended to south and north wing cracks; at the bottom, apophysis with water seepage was discovered. At that time, the basic sliding body formation was as shown in Figure 1.

The deformation and instability state of the west slope have continued over an extended time. A variety of studies have shown the effects of rainfall and vibration on slope instability. However, displacement monitoring data from the west slope during the rainy season in 2012 showed that the west slope did not show any large-scale deformation. Moreover, frequent blasting operations also did not cause large-scale deformation or sliding. Therefore, it can be concluded that water and vibration are not the only factors that influence slope stability; other factors also affect slope deformation and instability. In areas where geological structures are very complex, the coupling effects of tectonic stress and structural planes are likely to have crucial influences on the west slope deformation and instability.

\section{STRUCTURAL PLANE ANALYSIS}

There are four faults in the west slope from section 342 to 348 , namely, F1, F2, F3 and F4. The influence range of the F1 fault is the largest, as it cuts through all the four sections. The F2 fault appears in sections 344, 346 and 348 and is second only to the scope of the F1 fault. The F3 and F4 faults have only small sections in the deformation area of the west slope. Therefore, they are not the main faults that determine the deformation and stability of the west slope. According to the geological data, the location and direction of the F1 and F2 faults in the west slope are determined as shown in Figure 2.

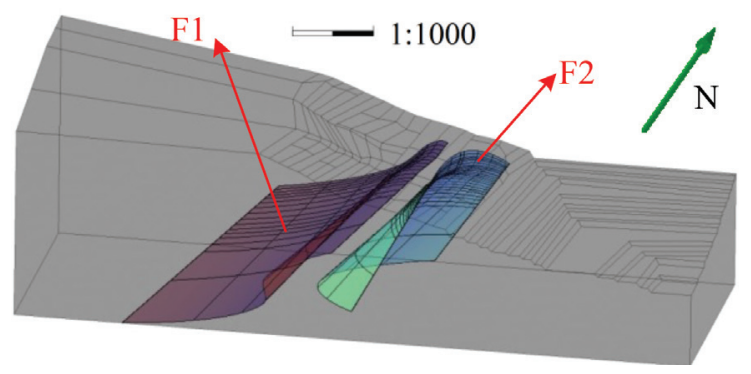

FIGURE 2. Distribution of the F1 and F2 faults, Buzhaoba open pit mine, China

Based on the occurrences and positions of the faults from Figure 2, the direction of the horizontal principal stress is perpendicular to the fault plane. Therefore, the tectonic stress on the fault will not cause super large-scale sliding following the strike direction of the fault. When the bottom of the sliding body meets special geological structures, such as faults and structural planes, there are two main forms of instability: One is unlocking sliding along the fault or structure plane, and the other is sliding 
out from inside the sliding body along the weakest sliding surface, as shown in Figure 3.

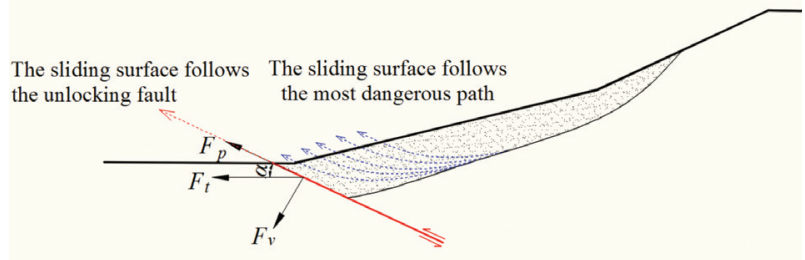

FIGURE 3. Fault plane unlocking conditions

When the sliding surface at the bottom of the sliding body extends along the fault or structure plane, it must satisfy the 'unlocking' conditions before sliding along the fault completely. At this time, the following mechanical conditions are met:

$$
F_{p} \geq F_{v} \tan \varphi
$$

where $F_{p}$ is the sliding force of sliding body along the direction of the structural plane and can be expressed as $F_{p}=F_{t} \sin \alpha ; F_{v}$ is the component force of sliding body perpendicular to the direction of the structural plane and can be expressed as $F_{v}=F_{t} \cos \alpha ; \alpha$ is the angle between the direction of the fault plane and the sliding body residue thrust at the bottom; and $\varphi$ is the friction angle of the fault plane.

Substituting $F_{p}$ and $F_{v}$ into (1), we obtain the following:

$$
F_{t} \sin \alpha \geq F_{t} \cos \alpha \tan \varphi
$$

$\tan \alpha \geq \tan \varphi$

It is discovered that when the angle $(\alpha)$ between the direction of the fault and the residue thrust of the sliding body at the bottom is larger than the friction angle $(\varphi)$ of the fault plane, the sliding body can freely extend along the fault or structure plane.

When $\alpha \leq \varphi$, the fault or structural plane reaches the condition of 'self-locking', which blocks the sliding body along the structural plane. The most dangerous sliding surface is one in which the sliding body can break away.

\section{RESULTS AND DISCUSSION}

\section{TECTONIC STRESS ANALYSIS}

To fully show the instability mechanism of the west slope at the Buzhaoba surface mine, we investigated the distribution of stress in this region from the perspective of the geological structure and regional terrain. The existing ground stress and deformation measurement data show that the development regularities of the ground stress field in China are as follows: The maximum principal stress direction of each area in China is similar to the angular bisector of the angle consisting of the attachment from this point to Chayu in China and Islamabad in Pakistan, and the direction is slightly deflected at the two side edges. When the research area is near Chayu, the actual maximum principal stress direction exhibits an anticlockwise deviation; when the area is near Islamabad, the actual maximum principal stress direction is the clockwise deviation.

According to the guidelines stated, attach the two lines from Buzhaoba mine area to Chayu and Islamabad; the angle between the two lines is $25^{\circ}$. Therefore, the horizontal principal stress direction is the angular bisector of the angle, as shown in Figure 4. The Buzhaoba mine area is near Chayu; thus, the maximum principal stress direction should deflect anticlockwise somewhat, and the horizontal principal stress direction can be determined by $123^{\circ}$.

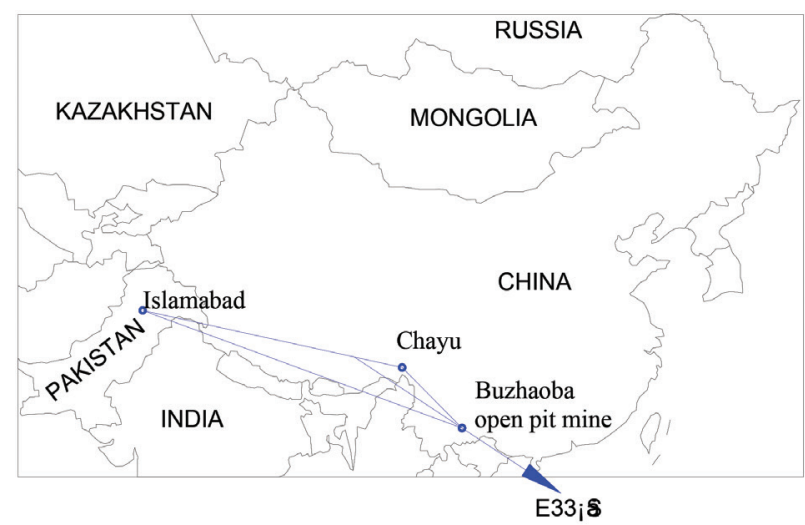

FIGURE 4. Principal stress directions of the Buzhaoba mine area

Horizontal tectonic stress exists in the initial rock seam, which has undergone long-term stress unloading and differentiation to the equilibrium state. Strip mining has broken the complete rock seam and destroyed the original equilibrium state of stress. The unbalanced stress (including tectonic stress) unloading and effect on the surface of slope can cause lithosphere deformation, relaxation and even rupture. Long-term monitoring data show that the displacement vector of the slope in the process of mining has anastomosed with the direction of horizontal tectonic stress, as shown in Figure 5; the blue line in Figure 5 represents the horizontal principal stress direction.

Through the analysis of the mine stope structure and the regional principal stress direction combined with the slope displacement monitoring data, this study has not only verified the validity of the principal stress direction but has also revealed the effects of tectonic stress on slope deformation and instability. These results play important roles for further understanding the west slope instability mechanism. 


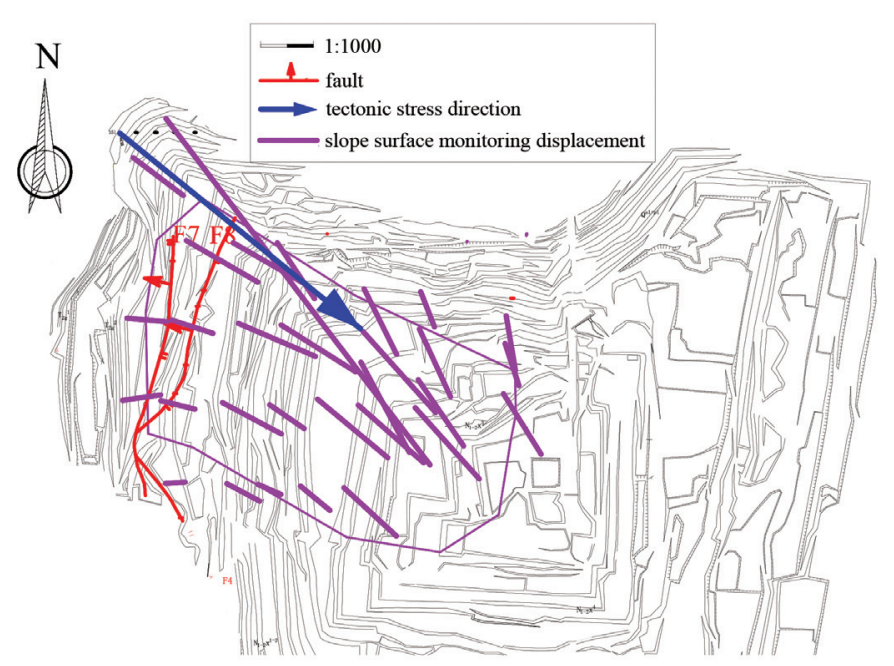

FIGURE 5. Displacement vector of the west slope and the direction of tectonic stress in the Buzhaoba open pit mine, China

\section{NUMERICAL SIMULATION OF THE WEST SLOPE STABILITY}

Through the analysis of the tectonic stress of the Buzhaoba surface mine, the principal stress direction was determined to be $123^{\circ}$. The effects of stress concentration on the northwest corner of the slope induce deformation of the west and north slopes to a high degree. According to the structure of the west slope, tectonic stress is added to the slope to analyze the stability of the west slope. The basic mechanical parameters of the rock seam in the west slope are as shown in Table 1. According to the geological structure of the west end-slope in the Buzhaoba open pit mine, FLAC3D was utilized to generate a model of the west end slope. The entire model has a width of $800 \mathrm{~m}$, a length of $2700 \mathrm{~m}$, and a height of $600 \mathrm{~m}$ and contains 1.5 million units, as shown in Figure 6. To analyze the stability of the west slope under conditions with and without considering the tectonic stress, the factor of safety was 1.29 and 1.39, respectively, as shown in Figures 7(a) and $6(\mathrm{~b})$, respectively.

A comparison of the two kinds of slope stability analysis results indicates that under the influence of tectonic stress, the sliding force increase, which causes the overall stability of the slope to decrease. To determine the effects of tectonic stress on slope stability and instability

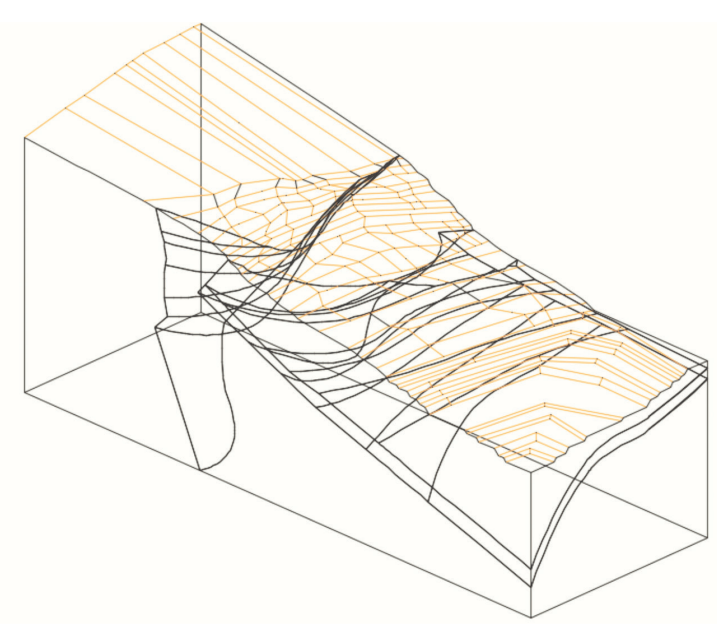

FIGURE 6. Numerical simulation model of the west end slope in the Buzhaoba open pit mine

mode, a profile was cut along the direction of principal stress at the stability analysis result model; the cut-through sliding surface is shown in Figure 8.

The sliding surface is relatively regulated and the sliding surface in the principal stress direction has a clear

TABLE 1. Physical and mechanical parameters of the rock mass in the west slope

\begin{tabular}{lcccc}
\hline \multirow{2}{*}{ Rock seam } & \multicolumn{2}{c}{ Physical property } & Residual shear strength $t_{\mathrm{r}}$ \\
\cline { 2 - 5 } & $\begin{array}{c}\text { Wet density, } \rho_{0} / \\
\mathrm{kg} / \mathrm{m}^{3}\end{array}$ & $\begin{array}{c}\text { Dry density, } \rho_{\mathrm{d}} / \\
\mathrm{kg} / \mathrm{m}^{3}\end{array}$ & $\begin{array}{c}\text { Internal friction angle, } \varphi\left(^{\circ}\right) \\
\text { Cohesion } C / \mathrm{kPa}\end{array}$ \\
\hline Plain fill $\left(\mathrm{Q}_{4}^{\mathrm{ml}}\right)$ & 1800 & 1400 & 9.6 & 15.98 \\
Clay $\left(\mathrm{Q}_{4}^{\mathrm{el+dl}}\right)$ & 1890 & 1260 & 8.71 & 18.24 \\
Clay rock $\left(\mathrm{N}_{1-2} \mathrm{x}^{1-2}\right)$ & 2000 & 1600 & 11.25 & 20.25 \\
Coal $\left(\mathrm{N}_{1-2} \mathrm{x}^{3}\right)$ & 1820 & 1940 & 10.17 & 13.34 \\
Argillaceous limestone $\left(\mathrm{T}_{2} \mathrm{~g}^{1}\right)$ & 2640 & 2610 & 21.9 & 101.7 \\
Dolomite limestone $\left(\mathrm{T}_{2} \mathrm{~g}^{2-3}\right)$ & 2680 & 2650 & 24.4 & 212.5 \\
\hline
\end{tabular}




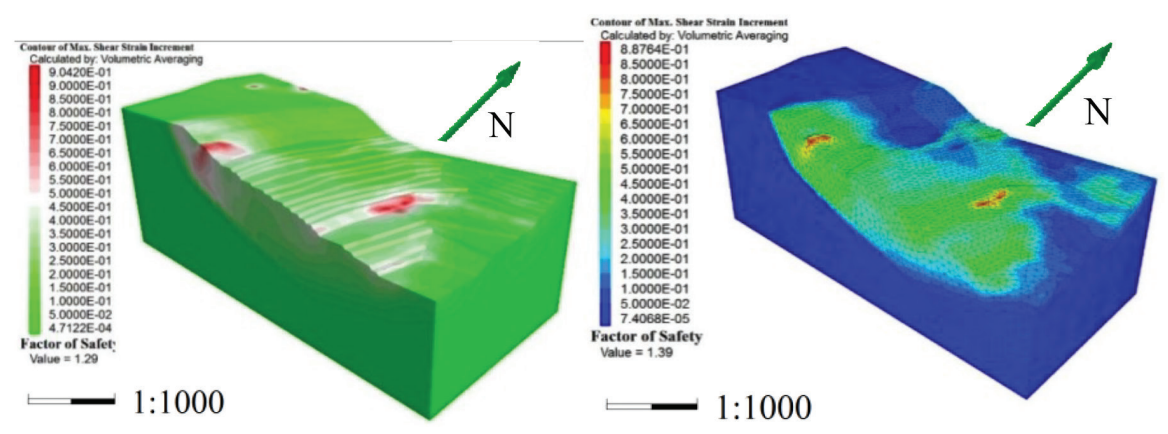

(a)

(b)

FIGURE 7. (a) Results of the stability analysis of the west slope with tectonic stress; (b) results of the stability analysis of the west slope without tectonic stress at the Buzhaoba open pit mine, China

plastic cut-through trend. A comparison of the plastic penetration in Figure 8 with the actual deformation range of the west slope indicates that the consistency is high, which fully shows that the tectonic stress and faults play an important role in the west slope deformation. In addition, the shear strain of the sliding body at the exposed position of F8 fault is the largest, which reveals the controlling effect on the potential sliding of the rock mass.

Tectonic stress has long existed in the rock seam and exerts a substantial impact on slope stability. In the process of long-term research, many scholars have focused on evaluating slope stability under the influence of tectonic stress and achieved useful results. This study analyses the long-term deformation and landslide problems of the west slope at the Buzhaoba mine in terms of depth. After combining the external influencing factors, such as water and vibration, we confirmed that the tectonic stress is one of the significant factors that affect slope stability. According to the regional structure analysis, the principal stress direction was determined. Through a comparison with field test data, the directions of stress and slope sliding are found to be the same; thus, the validity of the principal stress direction was verified. At the same time, this study evaluated the stability of the west slope based on a numerical simulation method. When tectonic stress was added, the slippery body structure was found to be similar to the actual sliding body at the west slope, which further proved the tectonic stress effect on the west slope.
Xia et al. (2016) studied the ground fluctuation caused by tectonic stress in the mining area. In their research, they divided the movement area into three different zones: The stability zone, the toppling zone and the landslide zone. The deformation of the footwall was found to be larger than that of central mining area under the influence of in situ stress and the formation mechanism of the rock mass collapsed under the influence of tectonic stress; the resulting fault was analyzed. A similar study was conducted by Xia et al. (2016), in which the formation mechanism of a rock mass under the influence of tectonic stress was investigated. We have also focused on analyzing the 'unlocking' mechanism of the sliding body along the fault under the influence of tectonic stress and structural plane, which is innovative compared to Xia's research. In addition, this research also calculated the three-dimensional slope stability and obtained the factor of safety to ensure practical value of the results of the analysis, where the factor of safety considering tectonic stress is 1.29 and that without considering tectonic stress is 1.39 , as shown in Figures 7(a) and 6(b).

The regional geological analysis done in our research is not detailed as that done by Tibaldi et al. (2015), who analyzed the deformation along the active Talas-Fergana fault induced by tectonic stress and gravity. However, the theoretical analysis and three-dimensional simulation for slope stability evaluation are more comprehensive. The principal stress direction is $123^{\circ}$.

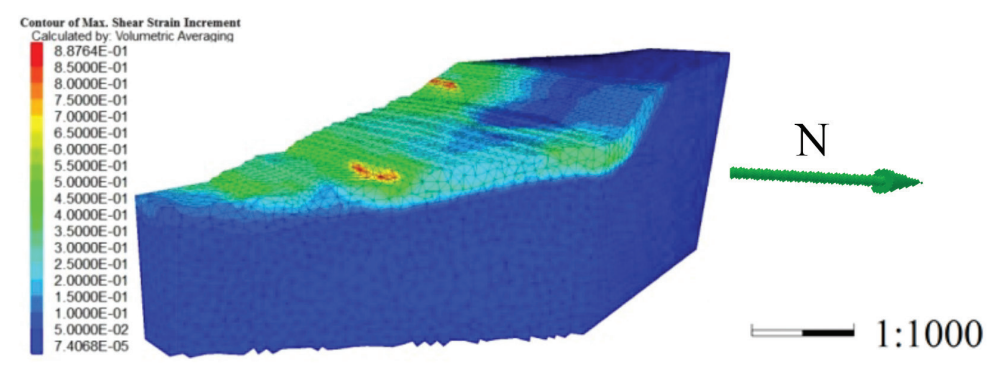

FIGURE 8 . Sliding surface cut-through along the principal stress direction 
This study explored the functional relationship between fault spacing and strength, and we focused on the combined effect of the faults and tectonic stress on slope stability. As noted by Zuza et al. (2017), our future research will extend the mechanical strength the experiment of the fault in the Buzhaoba mining area so that we can accurately identify the reasons for slope deformation.

Dhahri et al. (2016) studied a landslide in the Moulares phosphate mine and concluded that structure and geomorphology can control slope stability. They proposed that it is hard to control slope stability through engineering plans and reasonable land use. At this point, our opinion is that a mining plan is the best method to adjust slope stability, and we even applied a mining plan and engineering to recover coal resources of more than ten million tons; this success is based on the theory of time-dependent slope stability (Cai et al. 2008).

The effects of tectonic stress and control of structural planes on slope stability are reflected in many ways, and many researchers have conducted relevant research works. For example, Slim et al. (2015) studied the relationship between topographic stress and rock fracture. Wang et al. (2016) studied the control of tectonic evolution on sequence stratigraphic patterns and characterized four types of slopes with structural break zones. Safavian and Rezaei (2014) established landslide evaluation models of weak rocks and obtained satisfactory results.

Researchers have analyzed the effects of tectonic stress, faults and structural planes on slope stability from different aspects and have developed corresponding conclusions and results. This study evaluated the combined function of tectonic stress and faults and the deformation mechanism of the west slope at the Buzhaoba open pit mine was analyzed. The results characterize the impact of structural stress and faults on slope stability and lay a suitable foundation for further theoretical research and engineering applications.

\section{CONCLUSION}

Through a comprehensive analysis of the deformation and landslide problems of the west slope at the Buzhaoba open pit mine, the main factors associated with long-term slope deformation were identified as tectonic stress and structural planes. Based on research of the deformation mechanism and instability mode, the conclusions are as follows: The two main failure modes of slope and discriminant conditions are given under the comprehensive influences of tectonic stress and faults. When the angle between the direction of the fault and the sliding body residue thrust at the bottom is larger than the friction angle of the fault plane, the sliding body accesses the 'unlocking' slip along the fault or structural plane. If not, the fault or structural plane reaches the condition of 'self-locking', which leads to the sliding body acting along the most dangerous sliding surface inside the sliding area.
The principal stress direction of the Buzhaoba open pit mine area was determined to be $123^{\circ}$ according to the regional structural analysis; comparing the results of slope displacement monitoring and stability analysis, the validity of the principal stress direction was verified.

The factor of safety of west slope was 1.29 when considering tectonic stress and was reduced by $7.19 \%$ when tectonic stress was not considered. The shear strain of the sliding body was maximized at the exposed position of F8 fault, which proves the controlling effect of the fault on potential sliding of the rock mass.

Comparing the results of the stability analysis of the west slope "with tectonic stress and without tectonic stress', the sliding force was found to increase under the influence of tectonic stress, which caused the overall stability of the slope to decrease.

\section{ACKNOWLEDGEMENTS}

This work was financially supported by the Natural Key Research and Development Program of China (No. 2016YFC0501103). This publication was also based on work supported by the Government of Malaysia under a grant from the Fundamental Research Grant Scheme FRGS/1/2017/WAB08/UKM/02/1 and sabbatical leave granted under Universiti Kebangsaan Malaysia.

\section{REFERENCES}

Cai, M., Kaiser, P.K., Tasaka, Y. \& Minami, M. 2007. Determination of residual strength parameters of jointed rock masses using the GSI system. International Journal of Rock Mechanics and Mining Sciences 44(2): 247-265.

Cai, Q.X., Zhou, W., Shu, J.S., Liu, Y. \& Peng, H.G. 2008. Analysis and application on end-slope timeliness of internal dumping under flat dipping ore body in large surface coal mine. Journal of China University of Mining \& Technology 37(6): 740-744.

Can, E., Mekik, Ç., Kuşcu, Ş. \& Akçın, H. 2013. Monitoring deformations on engineering structures in Kozlu Hard Coal Basin. Natural Hazards 65(3): 2311-2330.

Chang, D.S., Zhang, L.M., Xu, Y. \& Huang, R.Q. 2011. Field testing of erodibility of two landslide dams triggered by the 12 May Wenchuan earthquake. Landslides 8(3): 321-332.

Chen, H.X., Zhang, L.M., Chang, D.S. \& Zhang, S. 2012. Mechanisms and runout characteristics of the rainfalltriggered debris flow in Xiaojiagou in Sichuan Province, China. Natural Hazards 62(3): 1037-1057.

Chen, Y., Wu, P., Yu, Q. \& Xu, G. 2017. Effects of freezing and thawing cycle on mechanical properties and stability of soft rock slope. Advances in Materials Science and Engineering 2017: 1-10.

Dhahri, F., Benassi, R., Mhamdi, A., Zeyeni, K. \& Boukadi, N. 2016. Structural and geomorphological controls of the present-day landslide in the Moulares phosphate mines (Western-Central Tunisia). Bulletin of Engineering Geology and the Environment 75(4): 1459-1468.

Fell, R., Macgregor, P., Stapleton, D. \& Bell, G. 2005. Geotechnical Engineering of Dams. London: Taylor \& Francis. 
Hack, R., Alkema, D., Kruse, G.A.M., Leenders, N. \& Luzi, L. 2007. Influence of earthquakes on the stability of slopes. Engineering Geology 91(1): 4-15.

Han, L., Shu, J.S., Hanif, N.R., Xi, W.J., Li, X., Jing, H.W. \& Ma, L. 2015. Influence law of multipoint vibration load on slope stability in Xiaolongtan open pit mine in Yunnan, China. Journal of Central South University 22(12): 4819-4827.

Han, L., Zhou, W., Shu, J.S., Wang, S.W. \& Meng, Q.W. 2014. Study of plane sliding timeliness stability and structure optimization of soft rock slope. Journal of China University of Mining and Technology 43(3): 395-401.

Martel, S.J. 2016. Effects of small-amplitude periodic topography on combined stresses due to gravity and tectonics. International Journal of Rock Mechanics and Mining Sciences 89: 1-13.

Mohamad, A.D.M., Ramli, M.F., Wan, N. \& Surip, N. 2010. Application of remote sensing in the identification of the geological terrain features in Cameron Highlands, Malaysia. Sains Malaysiana 39(1): 1-11.

Nian, T.K., Huang, R.Q., Wan, S.S. \& Chen, G.Q. 2012. Threedimensional strength-reduction finite element analysis of slopes: Geometric effects. Canadian Geotechnical Journal 49(5): 574-588.

Pradhan, B. 2013. A comparative study on the predictive ability of the decision tree, support vector machine and neurofuzzy models in landslide susceptibility mapping using GIS. Computers \& Geosciences 51(2): 350-365.

Rohmer, J. 2014. Dynamic sensitivity analysis of long-running landslide models through basis set expansion and metamodelling. Natural Hazards 73(1): 5-22.

Safavian, M. \& Rezaei, M. 2014. Evaluation of landslide analyzing models in weak rocks-case study: Abnahr damsite, Kohgilouyeh and Booyer Ahamd Province, Iran. Bulletin of Engineering Geology and the Environment 73(1): 87-94.

Shen, Y., Xu, G., Song, S., Li, Z., Feng, X. \& Dong, J. 2014. A classification method of surrounding rock mass in hydropower project in high geostress area. Chinese Journal of Rock Mechanics and Engineering 33(11): 2267-2275.

Shu, J.S., Tang, Z. \& Cai, Q.X. 2012. Research on stability of bedding rock slopes under hydraulic pressure. Zhongguo Kuangye Daxue Xuebao (Journal of China University of Mining \& Technology) 41(4): 521-525.

Slim, M., Perron, J.T., Martel, S.J. \& Singha, K. 2015. Topographic stress and rock fracture: A two-dimensional numerical model for arbitrary topography and preliminary comparison with borehole observations. Earth Surface Processes and Landforms 40(4): 512-529.

Taha, M.R., Khajehzadeh, M. \& El-Shafie,A. 2012. Application of particle swarm optimization in evaluating the reliability of soil slope stability analysis. Sains Malaysiana 41(7): 847-854.

Tan, W., Kulatilake, P.H.S.W. \& Sun, H. 2014. Influence of an inclined rock stratum on in-situ stress state in an open-pit mine. Geotechnical and Geological Engineering 32(1): $31-42$.

Tibaldi, A., Corazzato, C., Rust, D., Bonali, F.L., Mariotto, F.A.P., Korzhenkov, A.M., Oppizzi, P. \& Bonzanigo, L. 2015. Tectonic and gravity-induced deformation along the active Talas-Fergana Fault, Tien Shan, Kyrgyzstan. Tectonophysics 657: 38-62.
Wang, G., Wang, H., Gan, H., Liu, E., Xia, C., Zhao, Y., Chen, S \& Zhang, C. 2016. Paleogene tectonic evolution controls on sequence stratigraphic patterns in the Fushan sag, Northern South China Sea. Journal of Earth Science 27(4): 654-669.

Wang, T.T. \& Huang, T.H. 2009. A constitutive model for the deformation of a rock mass containing sets of ubiquitous joints. International Journal of Rock Mechanics and Mining Sciences 46(3): 521-530.

Wyllie, D.C., Mah, C.W., Hoek, E. \& Bray, J.J. 2004. Rock Slope Engineering. London: Civil and Mining, Spon Press.

Xia, K.Z., Chen, C.X., Fu, H., Pan, Y.C. \& Deng, Y.Y. 2016. Mining-induced ground deformation in tectonic stress metal mines: A case study. Bulletin of Engineering Geology and the Environment 75(3): 1-27.

Yang, J., Tao, Z., Li, B., Gui, Y. \& Li, H. 2012. Stability assessment and feature analysis of slope in Nanfen Open Pit Iron Mine. International Journal of Mining Science and Technology 22(3): 329-333.

Yoon, W.S., Jeong, U.J. \& Kim, J.H. 2002. Kinematic analysis for sliding failure of multi-faced rock slopes. Engineering Geology 67(1-2): 51-61.

Zhao, Y., Cui, P., Hu, L. \& Hueckel, T. 2011. Multi-scale chemomechanical analysis of the slip surface of landslides in the Three Gorges, China. Science China Technological Sciences 54(7): 1757-1765.

Zhou, W., Han, L., Shu, J. \& Meng, Q. 2016. Research on stability control mechanism of concave slope with circular sliding mode. Journal of China University of Mining and Technology 45(1): 70-76.

Zuza,A.V., Yin, A., Lin, J. \& Sun, M. 2017. Spacing and strength of active continental strike-slip faults. Earth and Planetary Science Letters 457: 49-62.

Shuzhao Chen, Liu Han \& Gerson. S. V. Tovele

School of Mines

China University of Mining and Technology

Xuzhou 221116

China

Shuzhao Chen \& Liu Han

State Key Laboratory of Coal Resources and Safe Mining

China University of Mining and Technology

Xuzhou 221116

China

Goh Thian Lai*

School of Environmental and Natural Resource Sciences

Faculty of Science and Technology

43600 UKM Bangi, Selangor Darul Ehsan

Malaysia

*Corresponding author; email: gohthianlai@ukm.edu.my

Received: 4 May 2018

Accepted: 25 October 2018 